\title{
THE MAIN STRATA OF THE CHUVASH PERSONAL NAMES IN THE PRE-CHRISTIAN PERIOD
}

\author{
Eduard V. Fomin ${ }^{1}$, Alena M. Ivanova ${ }^{2 \star}$ \\ ${ }^{1}$ Assoc. Prof., Chuvash State Institute of Culture and Arts, RUSSIA, ehuma@rambler.ru \\ ${ }^{2}$ Prof, Dr., I. N. Ulyanov Chuvash State University, RUSSIA, amivano@rambler.ru \\ ${ }^{*}$ Corresponding Author
}

\begin{abstract}
Thousands of traditional names make up a significant layer of the Chuvash language lexical system. Genetically, the Chuvash anthroponyms are divided into Chuvash, Tatar, Arabic, Iranian and Russian basic strata. The ethnic identity of the anthroponymic system is formed by the Chuvash original names. A twostage naming system in the Chuvash language included both the main taboo names and the names that replaced them in everyday life. A significant layer of Tatarisms is singled out among the Chuvash anthroponyms. They compete with the Chuvash names. The Chuvash-Tatar kinship relations and the significant influence of the Tatar culture on the Chuvash in the post-Bulgarian period determine their use. Numerous Tatar and Iranian names have the Tatar roots. The Chuvash name-building on the basis of various combinations of the same components is possible due to the anthroponyms of Islamic origin, namely to the Arab-Iranian and Tatar units. Tatar, Arabic and Iranian names ensure the existence of a common fund of personal names in the Volga-Kama language union. The Russian-Orthodox anthroponymic subsystem mainly includes ancient Greek, Latin and proper Russian names. Being adapted to the peculiarities of the Chuvash language they have undergone significant phonetic, derivational and semantic changes. The Russian names of the 18th century that appeared in the Chuvash language are qualified as both Orthodox and pagan. They are an intermediate link between pagan and modern names which completely coincide with European Christian anthroponyms. The unique fund of the pre-Christian Chuvash names exists due to the onyms combination with various linguistic and genetic basis. It is the phenomenon of a different cultural reality.
\end{abstract}

Keywords: personal names, onomastics, language contacts, the Chuvash language

\section{INTRODUCTION}

Onomastic studies in Chuvash linguistics are not among the priorities. Meanwhile, the names have great potential, opening up new knowledge and research aspects in the field of history of the Chuvash language and linguistic contactology. It is necessary to recognize the primary, traditional onomastic material as an equal part of the Chuvash lexical system.

The names of the pre-Christian epoch are still the usual background of the Chuvash word culture. In particular, they are still found in colloquial speech in the form of names of Christian origin that assimilated with Chuvash ones (Leont'eva, 2006), predominate in fiction (Fomin, Ivanova, 2016). They arouse considerable interest in the scientific and everyday environment, but have not yet received a holistic coverage, which seems unfair. Pagan names are a phenomenon of a different cultural reality, largely mysterious and unknown, capable of clarifying traditional views in Chuvash studies and even more - of forming new theories in the history of the Chuvash language. 
According to the periodization proposed by N. I. Egorov, the following epochs should be highlighted in the development of the Chuvash anthroponymicon:

1. Ancient Bulgarian (IV-VII centuries), reflected in Persian, Byzantine, Syrian and other historical sources by the names of Bulgarian khans;

2. Middle Bulgarian (VIII-XVI centuries), including the following periods:

2.1. The period before the Golden Horde (VIII-XII centuries), which continued the ancient Bulgarian traditions;

2.2. The period of the Golden Horde (XII-XIV centuries), known for the names of all-Turkic origin in the Kipchak phonetic decoration and Muslim anthroponyms of Arab and Persian origin;

2.3. The period of the Khanate of Kazan ( $X V-X V I$ centuries), mainly represented by the Tatar anthroponymicon;

3. the New Bulgarian (Chuvash) epoch (from the XVI century to the present), which initially preserved the Islamic anthroponymicon with a gradual transition to Christian names (Egorov, 1986, p. 95-97).

Most of the traditional Chuvash names belong to the Golden Horde, Khanate of Kazan and New Bulgarian epochs. Tatarisms, Arabisms and Iranisms absolutely fair prevail in the Chuvash anthroponymic dictionary. The layer of names that has not yet been etymologized is probably represented by the names of earlier epochs - the one before the Golden Horde, Middle and even Old Bulgarian.

\section{METHODOLOGY}

The purpose of this study is to identify the genetic strata of the anthroponymic system of the Chuvash language of the pre-Christian epoch on the basis of etymological research, to describe their linguistic features and to establish relationships between private national anthroponymic subsystems and others within the framework of the Chuvash onomasticon.

The research material is a corpus of Chuvash anthroponyms, collected by the authors of this work. It contains five thousand names of the pre-Christian epoch, mainly codified in the Chuvash dictionary of N. I. Ashmarin (Ashmarin, 1928-1950), the book "Chuvash Pagan Names" by V. K. Magnitsky (Magnitskii, 1905), numerous folklore texts, toponymic reference books, historical researches and documents.

The following research methods are used in this paper:

1) Etymological, which involves the use of phonetic, derivative, and semantic methods with the involvement of a wide historical and linguistic context;

2) Lexicographical, allowing to consider traditional Chuvash names as a systemic phenomenon;

3) Statistical, characterizing linguogenetic strata of names in quantitative terms.

\section{RESULTS}

The Chuvash anthroponymic dictionary consists of many linguistic strata (see Table 1). At the same time, the anthroponymicon is dominated by the Turkic layer, which includes the Chuvash, Tatar and all-Turkic layers $(54.9 \%)$.

Table 1. Linguogenetic stratification of pre-Christian Chuvash names

\begin{tabular}{|l|c|c|l|c|c|}
\hline \multicolumn{1}{|c|}{ Names } & $\begin{array}{c}\text { Absolute } \\
\text { number }\end{array}$ & $\begin{array}{c}\text { Part, } \\
\text { in } \%\end{array}$ & \multicolumn{1}{|c|}{ Names } & $\begin{array}{c}\text { Absolute } \\
\text { number }\end{array}$ & $\begin{array}{c}\text { Part, } \\
\text { in \% }\end{array}$ \\
\hline Chuvash & 1544 & 30.9 & Turkic & 126 & 2.5 \\
\hline Tatar & 1076 & 21.5 & Russian & 92 & 1.8 \\
\hline Arabian & 743 & 14.8 & Scandinavian & 15 & 0.3 \\
\hline Ancient Greek & 608 & 12.2 & Mongolian & 10 & 0.2 \\
\hline Iranian & 366 & 7.3 & Mari & 6 & 0.1 \\
\hline Hebrew & 263 & 5.3 & Total & 5000 & 100.0 \\
\hline Latin & 151 & 3.0 & & & \\
\cline { 1 - 3 } & & & &
\end{tabular}


Since the basis of naming is such an extra-linguistic factor as the religious consciousness of native speakers, conditionally strata can be combined into three enlarged supra-ethnic formations (see Table 2).

Table 2. Genetic stratification of Chuvash pre-Christian names, taking into account the religious component

\begin{tabular}{|l|c|}
\hline \multicolumn{1}{|c|}{ Names } & Part, in \% \\
\hline Pagan (Chuvash, Mongolian, Mari) & 31.2 \\
\hline Islamic (Tatar, Arab, Iranian, Turkic) & 46.1 \\
\hline Christian (ancient Greek, Hebrew, Latin, Russian, Scandinavian) & 22.7 \\
\hline Total & 100.0 \\
\hline
\end{tabular}

The Chuvash pre-Christian anthroponymicon is based on the proper Chuvash, Tatar, Arabic-Iranian and Russian (conditionally) onomasticon.

\subsection{Names of Proper Chuvash Origin}

In the epoch of paganism, the entire life of the Chuvash people was ritualized. A special role was given to the rituals associated with the birth of a child, in particular, to naming. In the perception of the Chuvash people in the pre-Christian epoch, the selection of a name was a particularly important task, designed to determine the future of man.

The Chuvash tradition originally assumed a double naming of a person. The first name is official, taboo, as a rule, benevolent, positive Ëlkkempi 'beautiful mistress', Itelmes 'the dog won't take', Merčen 'pearl', Šorkka 'white'; the second one is domestic, discordant, usually with derogatory semantics Kurak 'rook', Süppi 'weedy', Xărăm 'soot'. The named specificity was formed under the influence of pagan representations of the Chuvash people, according to which evil spirits could harm a person with an open name, so their it was assumed to taboo them, followed by the replacement of the main hidden name with a household one.

Scientists agree that the ethnography of the Old Chuvash naming convention is reduced to a single complex (Petrov, 1986, p. 75), moreover, it organically fits into the general Ural-Volga context (Egorova, 2010, p. 110).

The system of the ancient Chuvash naming convention began to actively disintegrate from the middle of the XVIII century, when decisive steps were taken to Christianize the non-Russian peoples of the Volga region. During this period, the Chuvash anthroponymicon became much more complicated. On the one hand, there was its own tradition of naming, on the other - the Russian system, which brought Orthodox names to the Chuvash environment.

The replacement of pagan names by Orthodox ones was uneven among the Chuvash people. By the beginning of the XIX century, almost the entire Chuvash metropolis has already switched to new anthroponyms borrowed in a substitution form, cf.: Andrey $\rightarrow$ Untri / Entërkke / Entrey / Entri; Ekaterina $\rightarrow$ Katuś / Kat'uk / Kĕteri / Kĕterin / Kĕterne / Kĕterni / Kĕteruk.

The situation was different in the periphery, which was more committed to pagan traditions: in the Chuvash communities of the Ural-Volga region, traditional names were encountered until the middle of the 20th century (Petrov, p. 75).

Proper Chuvash names of the pre-Christian epoch are represented by the following structural varieties:

- Names equal to appellative: Pattăr 'hero'; Părčkan 'wagtail';

- Names formed from the appellative with the identifying affix -i: Avanni 'the best'; Savni 'the one who is loved';

- With two-root names: Kĕmĕlpi < kĕmĕl 'silver' + pi(ke) 'madam'; Tutimĕr < tu 'mountain' + timĕr 'iron';

- Names with derivative deminutive affixes: Avantey < avan 'good' + -tey; Virăstay < vïrăs 'Russian' / vïrsarni (kun) 'Sunday' + -tay.

In general, the anthroponymy of Chuvash origin itself is the strongest creative field of language activity, which consists in a specific linguistic system of name formation and functioning of names. In the epochs of great historical upheaval, the Chuvash anthroponymicon was subject to a significant influence of foreign languages, but nevertheless managed to preserve the basic elements. 


\subsection{Names of Tatar Origin}

Tatar names compete with proper Chuvash names. It seems that the unique Chuvash anthroponymicon of the XVIII century, recorded by scientists, is predominantly a Tatar stratum.

Development of Tatar names in the Chuvash environment is associated with the entry of the Chuvash region in the Golden Horde, and then in the Kazan Khanate. The influence of Islam on the Chuvash people was significant (Yagafova, 2009, p. 10-60), in particular, it changed the onomastic system, which was rebuilt in the Tatar way: many Chuvash villages had Tatar names, Tatar names flooded into the Chuvash environment.

An important feature of Tatar names is associated with such a feature as the entry into an indissoluble connection of name-forming components with Arabic and Persian formants: Aykine from Tatar Aygaynə (ay 'moon' + Arabic عين (Ayna) 'eye'), Išmey from Tatar lšmehəmmət (iš 'pair, coeval' + Arabic (Mukhammad), Pimărsa from Tatar Bikmorza (bək 'lord, prince' + Persian ميرز (murza) the same).

A common feature of Tatar names is the maximum concentration of positive etymological significance, the focus on ensuring the welfare of the carrier, cf.: Aykul from Tatar ay 'moon', gel 'flower'; Irpay from Tatar ir 'man', bay 'rich; master'; Kolmărsa from Tatar kol 'servant of God', morza 'mirza'; Mineslu from Tatar minle 'with a mole', sïlu 'beautiful'.

Phonetics of names-Tatarisms, as a rule, assumes the preservation of the original sound, only slightly subjected to substitution, cf.: Tatar Aktirek, Tuybike, Urasbay, Čulpan, Yammurza - Chuvash Akterek / Axtirek, Tuypike, Uraspay, Čulpan, Yamorsa. On the one hand, this was due to the fact that the languages in question were related, on the other hand, due to the prolonged contacts and the prevalence of Chuvash Tatar bilingualism.

Substitution allows for the variation of names within the limits of maintaining an open etymological connection, cf.: Ilparăs / Ilpars / Ilporăs from Tatar Ilbar(i)s, Kăspike / Kăspikke from Tatar Kïzbikə, Payparăs / Payparăš / Payparis / Paypars from Tatar Baybar(i)s.

Some names have changed a lot: Paymuk, Paimoš, Paymuś, Paymuxa, Paymuxxa, Paymuš $\leftarrow$ Tatar Baymөхәmmət; Tuymit $\leftarrow$ Tatar Tuymөхәmmət; Ureśey $\leftarrow$ Tatar Urazay; Uxtimĕr $\leftarrow$ Tatar Aktimĕr, Ürmekke $\leftarrow$ Tatar Urazmexəmmət.

Morphonologically, names may have different degrees of cohesion of the constituent elements:

- Weak: Xorăspulat from Tatar Korïčbulat, where korïč 'steel', bulat the same; Čorapaš from Tatar Čorabaš, где čora 'warrior, warlord', baš 'head';

\section{- Strong: Irmet / Irmemet from Tatar IrmeXəmmət; Urmet from Tatar UrazmөХəmmət.}

In the field of derivation, Tatarism is characterized by complexity. The vast majority of Tatar names are tworooted, which is dictated by the creative approach to name formation, the desire to invest more useful potential and goodwill in the name.

From the point of view of derivative typology, all the variety of names of Tatar origin in the Chuvash language is represented by the following models:

\section{Simple names:}

1.1. Name equal to the root: Issen from Tatar isən 'healthy'; Kĕměš from kemeš 'silver'; Tenis from Tatar diңez 'sea';

1.2. Root + name-forming formant: Iltey from il 'country' + -tey; Terek from tere 'living' + -ek;

2. Compound names:

2.1. Adjective + noun: Paypike from bay 'rich' + bikə 'mistress'; Salmat from sal 'healthy' + Mexəmmət;

2.2. Noun + noun: Ayšat from ay 'moon' + šat 'happiness'; Memeš from Mexəmmət) + iš 'pair, coeval';

2.3. Noun + adjective: Iltula from il 'country' + tulï 'full';

2.4. Noun + verb: Eškilt from yaš 'young man' + kilde 'came'; Tinpaxta from tiң 'equal' + baktï 'was born';

2.5. Verb + noun: Kilčura from kil- 'come' + čura 'servant of God'.

Attention is drawn to such a peculiarity of the names, as their full-phrasal character (see 2.4).

The most interesting point in the functioning of the Chuvash names of Tatar origin is the developed 
compatibility of components with each other, which eventually creates an anthroponymic system with potentially infinite possibilities to form a diverse onomasticon (see Table 3).

Table 3. Combinability of name-forming components

\begin{tabular}{|c|c|c|c|}
\hline Pulat, pălat 'steel' & Par(ă)s 'leopard' & Tirek 'poplar' & Timĕr 'iron' \\
\hline Aypulat & - & Aytirek & - \\
\hline Axpălat & Akparăs & Aktirek & Aktimĕr \\
\hline- & Ilpars & - & Iltimĕr \\
\hline Irpălat & - & - & - \\
\hline Isampulat & - & Isentirek & Isentimĕr \\
\hline- & Išpars & Ištirek & Ištimĕr \\
\hline Korăspălat & - & - & - \\
\hline Paypălat & Paypars & Paytirek & Paytimĕr \\
\hline Pikpulat & Pikpars & Piktirek & Piktimĕr \\
\hline Pitpulat & - & Pittirek & Pittimĕr \\
\hline Pixpulat & - & - & Pixtimĕr \\
\hline- & - & Saltirek & - \\
\hline Taypălat & - & - & - \\
\hline- & Tănpars & - & - \\
\hline Tinpălat & - & - & - \\
\hline Tokpălat & - & - & - \\
\hline Torpălat & - & - & - \\
\hline Tuypălat & Tuypars & Tuytirek & Toytiměr \\
\hline Uraspulat & - & - & - \\
\hline Xorpălat & - & - & - \\
\hline Čănpălat & - & Čăntirek & Čăntimĕr \\
\hline Čorapălat & - & - & - \\
\hline Šixpulat & - & - & - \\
\hline- & - & Yamantirek & - \\
\hline Yanpălat & Yampars & - & - \\
\hline Yašpulat & Yašpars & Yaštirek & Yaštimĕr \\
\hline
\end{tabular}

The broad admission of Tatarism in the Chuvash anthroponymicon is due to the kinship of the Chuvash and Tatar languages. At the same time, names of Tatar origin cannot be analyzed by means of the Chuvash language, and in this case they have an advantage over the names of proper Chuvash origin. Meanwhile, tatarism-anthroponyms possess important qualities that allow to produce a significant number of names on the material of limited language means.

\subsection{Names of Arab and Iranian Origin}

Arab and Iranian borrowings are one of the mysterious and attractive topics in Chuvash linguistics. According to approximate estimates, in the modern Chuvash language there are at least three hundred of them and two-thirds of the borrowings are Arabic words (Skvortsov, 1968, p. 139-140).

Phonetic development of Arabic-Iranian names was carried out in two stages: at first, they underwent

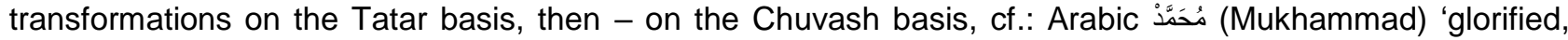
praised' $\rightarrow$ Tatar Mexəmmət $\rightarrow$ Chuvash Măxamat / MăXXit; Arabic عبد الرحمن : Abdurrakhman) 'servant of the 
merciful' $\rightarrow$ Tatar Abdaraxman $\rightarrow$ Chuvash Trexmen; Iranian زلف (Zulf) 'curls' $\rightarrow$ Tatar Zelife $\rightarrow$ Chuvash Selixe.

Observations show that the Chuvash realizations are phonetically farther from the Arab-Iranian prototypes than the Muslim Tatar ones. This is due to the Islamic religion based on the Arabic language, as well as the specifics of the sound system of the Chuvash language itself.

Chuvash names dating back to the Arab-Iranian etymons are characterized by the following phonetic transformations: substitution (Keleya from Arabic غالية (Galiya); Parxat from Arabic فرحات (Farkhat); Sarixva from Arabic ظريفة (Zarifa)); synharmonization (Vesile from Arabic وسيلة (Vasilya); Kerim from Arabic الكريم فات (Raka) (Karim)); prothesis (Äraxxille from Arabic رأخيل (Rafil); Erxime from Arabic رحمة (Rakhima)); apheresis (Ekime from Arabic ككيمة (Xakima)); epenthesis (Äymanissa) from Arabic أمان (Aman), نساء (nissa); Kĕlěsăm from

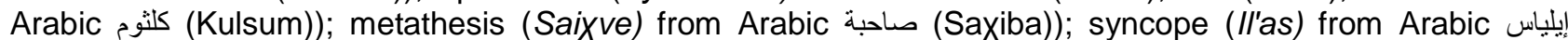
(Ilyas); Mamet from Arabic محا (Mukhammad)); apocope (Măxip from Arabic هحبة (Mukhibba), Šăxal' from Iranian شيخ المال (Shakhigalim)).

In terms of derivation, the names of Arab and Iranian origin can be divided into simple and complex names:

\section{Simple names:}

1.1. Arabisms: Islam from Arabic إسلام (Islam) 'obedience, surrender to Allah; acceptance of Islam'; Karăm from Arabic رضي (Karim) 'magnanimous'; Rsi from Arabic رضا (Reza) 'pleasure; consent; favor';

1.2. Iranisms: Ikun'a from Iranian يكانه (Yegane) 'the only one'; Katey from Iranian katta 'big' + -ey; Ristem from Iranian رستم (Rustam) 'mighty, strong';

2. complex names:

2.1. Arabism + Arabism: Mirkali from Arabic أمير (Amir) 'king, ruler, prince', علي (Ali) 'high, sublime'; Epxerin from Arabic أبو (Abu) 'father', كريم (Karim) 'generous, benevolent, noble, benevolent, hospitable';

2.2. Arabism + Iranism: Aynakăl from Arabic عين (Ayna) 'eye', Iranian جل (gul') 'flower', literally 'flower-eyed'; Elimša from Arabic عالم (Alim) 'scientist', Iranian (shakh) 'monarch; sovereign, lord'; Ekhmetian from Arabic أحمد (Akhmet) 'the one who always thanks God', Iranian جان (dzhan) 'soul';

2.3. Iranism + Iranism (Xočaš) from Iranian خواجه (Khodzha) 'master', شاه (shakh) 'monarch; sovereign, lord'; Šervustan from Iranian شهر (shäkhr) 'town', بوستان (bustan) 'flowerbed';

2.4. Iranism + Arabism: Akasal > Iranian اغاز (Agaz) 'beginning', Arabic علي (Ali) 'high, sublime'; Tusmat from Iranian بار (dust) 'friend', Arabic غيب (Kukhammad); Xaypăla Iranian غيب (Khaib) 'invisible, hidden', Arabic اله 'اله (Allah), literally 'the innermost [knows] Allah'.

However, Arab and Iranian formants, becoming popular, often begin to act as an independent name-forming function in conjunction with the Tatar foundations: Ayămnissa from Tatar ayïm 'my moon', Arabic نساء (nissa) 'women', literally 'my moonlike woman'; Aypălat from Tatar Aybulat, in which ay 'moon', Iranian بو لات (bulat) Iranian 'steel'; Ilmemet from Tatar il 'country', Arabic (Mukhammad) 'praised, worthy of praise'; Ilsever from Tatat il 'country', Iranian سوار (zivar) 'jewellery'; Minulla from Tatar miң 'birthmark', Arabic -ulla (Allah) 'God'; Savkirey from Tatar sau 'healthy', Iranian غاراي (Keray) 'strong, powerful'; Savreslu from Iranian سوار (Sivar) 'jewellery', Tatar sylu 'jewellery'.

Very often, names can no longer be called Arabic or Iranian in the full sense of the word, because they do not exist in the original languages, and they have occurred on either a Tatar or Chuvash basis.

In the course of the Chuvash language acquisition, Arabic-Iranian names allowed for the extension of affixes: Sevruk > Iranian سوار (Sivar) 'jewellery' + -uk; Taruś > Iranian داريوش (Daryush)) 'little owner'; Uśmentey) > Arabic عثمان (Usman) 'a chick of a bird similar to a cuckoo' + -tey.

Semantic acquisition of Arabic and Iranian names in the Chuvash language was rare. Only a few cases due to folk etymology have been recorded: 1) араб. أصيل (Asiil) 'noble, of noble origin, thoroughbred, purebred, genuine, real' $\rightarrow$ Chuvash aslă 'senior, glorious, big, great, major': Aslăpike from Tatar Asïlbikə; 2) Arabic عادل (Adil') 'fair' through Tatar Adil, Gadil, Gadel $\rightarrow$ Chuvash Atăl 'Volga': Atălkka, Atălsulttan; 3) Iranian ستاره (setare) 'star' $\rightarrow$ Chuvash serte 'aegopodium': Sertepi.

A distinctive feature of the Arabic and Iranian anthroponyms is their participation in the formation of a common fund of personal names of the peoples of the entire Ural-Volga region. In this regard, anthroponyms-Arabisms and Iranisms are an important component that forms the Volga-Kama language union. 


\subsection{Names of Russian Origin}

Orthodox names in the Chuvash phonetic design are a kind of transitional layer of names between authentic pagan and Orthodox anthroponyms in their modern sounding.

Phonetic adaptation of Russian names to the requirements of the Chuvash language is the main method of their becoming like Chuvash. The main substitutional processes in the Chuvash environment are aimed at replacing the voiced consonants of the Russian language, as well as [f] and [c] the closest matches, cf.: Artemiy $\rightarrow$ Urtt'um, Gavrila $\rightarrow$ Kavărle, Darya $\rightarrow$ Tarye, Fiodor $\rightarrow$ Xĕvetĕr, Khristina $\rightarrow$ Xriśti.

In the development of Russian names there are other phonetic processes: insert of prothesis (Rodion $\rightarrow$ Ărtivan, Spiridon $\rightarrow$ Éśpritun); infixation (Iuda $\rightarrow$ Iyută, Illarion $\rightarrow$ Larivan); apheresis (Elizar $\rightarrow$ Lisar, Iulita $\rightarrow$ Ulitta); metathesis (Artemiy $\rightarrow$ Utremen, Evgeniy $\rightarrow$ EXveni); syncope (Dorimedont $\rightarrow$ Tărmitun); diaeresis (Gavrila $\rightarrow$ Karila); apocope (Anastasiya) $\rightarrow$ Naśtaś), V'acheslav $\rightarrow$ Viččasla).

These phenomena are combined in different ways, complicating the structure of felt Russian names, cf.: Konstantin $\rightarrow$ Kăśtuk, where there's a transition $o>$ ă and diaeresis $n$; Ksenofont $\rightarrow$ Śïnaxvun, where there's apheresis $k$, sound transitions $e>\ddot{I}, 0>u$, substitution $f \sim X v$, apocope $t$.

A significant role in the development of Russian anthroponyms in the Chuvash language belongs to the emphasis. In the Chuvash variants it is, as a rule, transferred to the final syllable, cf.: Grigóriy $\rightarrow$ Kĕrkurí, Daníla $\rightarrow$ Tanilé, Vásya (Vasiliy) $\rightarrow$ Vaśśá), Dárya $\rightarrow$ Tarí, Klávdia $\rightarrow$ Klavyé, Natália $\rightarrow$ Nattá, Feodósia $\rightarrow$ Xvetuśśá. Retention of stress on the original syllable is rare: Gerásim $\rightarrow$ Káračăm, Ósip $\rightarrow$ Úśăp, Prókhor $\rightarrow$ PrúXXăr. The transfer of stress on the first syllable is observed in exceptional cases: Maksím $\rightarrow$ Mákśăm.

A notable feature of the Russian names that have moved into the Chuvash language is the multivariant nature of the names, which is implemented within the limits of allowable sound combinations, cf.: Mikhail $\rightarrow$ ${ }^{1}$ Milak, ${ }^{2}$ Miśuk, ${ }^{3}$ Mixala, ${ }^{4}$ Mixali, ${ }^{5}$ Mixalkka, ${ }^{6}$ Mixal'a, ${ }^{7}$ Mixali, ${ }^{8}$ Mixal'uk, ${ }^{9}$ Mixalkka, ${ }^{10}$ Mixele, ${ }^{11}$ Mixel'u, ${ }^{12}$ Mixi, ${ }^{13}$ Mixuk, ${ }^{14}$ MixXa, ${ }^{15}$ Mixxay, ${ }^{16}$ MixXayla, ${ }^{17}$ MixXal', ${ }^{18}$ MixXi, ${ }^{19}$ MixXuk, ${ }^{20}$ Mišša. The observed variability of personal names in the Chuvash language is primarily explained by their initial diverse implementation in the Russian environment itself (Miša, Mišen'ka, Miška, Mišul'a, Mišun'a, Mixa, Mixay, Mixan'a, Maxas'a) and, in the next place, by the specific features of the receiving Chuvash dialects.

The broad limits of name variability create the conditions under which they begin to enter into a

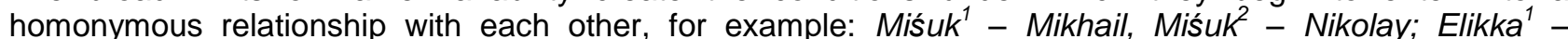
Aleksey, Elikka ${ }^{2}$ - Aleksandr; Mal'uś ${ }^{1}$ - Melania, Mal'uśs ${ }^{2}-$ Maria; Nat'uk ${ }^{1}$ - Nadezhda, Nat'uk ${ }^{2}-N^{2}$ atalia.

Active word-formation development of Russian names by the Chuvash language was also made through affixation.

In the Chuvash language, there are special affixal and appellative means of name formation (see more in: (Fedotov, 1998, p. 20-32). The following affixes are most in demand in the development of Russian names:

-(k)ka / -(k)ke: Elinkka ‘Elena', Emelkke ‘Emelyan', Karakka 'Gerasim', Simkka 'Semion';

-uk / -ük / -yuk / -ok: Vaśśuk 'Vasiliy', L’upuk 'L'ubov', Ot’ok 'Evdokiya', Pet'uk 'Piotr';

-uś / -üś / -yuś: Kăttuś ‘Ekaterina’, Lavruś 'Lavrentiy’, UXruś ‘Efrosiniya’;

-uš) / -üš: L'avuš 'Lev', Pavluš 'Pavel', Petruš 'Piotr';

-ška / -ške: Kantraška 'Kondratiy', Śinuška 'Zinaida', Xvetuška 'Fiodor'.

There is an unusual situation in the derivative development of names: process of making Russian anthroponyms like Chuvash occurs through the use of Russian suffixes, on the Chuvash soil devoid of deminutive semantics, cf.: Emel'ka (Emelyan) $\rightarrow$ Emelkke, Kat'usha (Ekaterina) $\rightarrow$ (Kătt'uś), Ermoshka (Ermolay) $\rightarrow$ Yarmuška.

Semantic development of Russian names is associated with the appeal to folk etymology and is reduced to the selection of associative Chuvash analogues of the pre-Christian epoch, and in some cases-to comparison with the appellative vocabulary and adaptation of borrowed names to them on the phonetic and derivational levels, cf.: Kăsïyan 'Kasyan' - kăsăya 'titmouse', Măkkăl' 'Nikolay' -măkkăl' 'cone', Ulatimĕr 'Vladimir' - ula timĕr 'mottled iron', Kul'kka 'Akulina' - kul'kka 'pigeon'.

Russian names in the Chuvash context can be not only Christian, but also pagan names. Materials of the N.I. Ashmarin's dictionary of the Chuvash language testify that the qualification of the name is conditioned by the religious consciousness of its bearer, cf.: Nat'uk 1. pagan name. 2. Nadezhda. 3. Natalia (Ashmarin, 1928-1950, v. 9, p. 14); Yakrav 1. Christian Evgraf. 2. pagan name (Ashmarin, 1928-1950, v. 4, p. 172). 
In some cases, in borrowing Russian anthroponyms by the Chuvash language there is an unusual selection of parallel names, for example: Otok $=$ Anton, T'akkăm $=$ Maksim, Yulpike $=$ Xristina. These examples probably reflect the tradition of combining an unofficial pre-Christian name with an official Orthodox name given to the same person at birth and baptism.

Russian names, penetrating into the Chuvash language through oral means, were subjected to various changes-mainly phonetic, sometimes word-forming, rarely semantic. As a result, the original names could be transformed beyond recognition. However, this kind of transformation allowed the formation of a unique system of Chuvash anthroponyms of Orthodox origin.

\section{CONCLUSIONS}

The traditional pagan anthroponymicon of the Chuvash language is Turkic in linguistic terms and Islamic in religious terms. Arabisms and Iranisms entered the Chuvash language through the medium of Tatar. Tatar, Arabic and Iranian names ensure the existence of a common fund of personal names in the Volga-Kama language union.

The foreign-language onomasticon is deeply embedded in the lexical system of the Chuvash language. Borrowed names on a Chuvash basis have passed through phonetic, word-formation and semantic transformations. Most likely, their number exceeds the lexical fund of the Chuvash language. To a large extent, the diversity of names is dictated by common naming models that allow for a wide range of component combinations.

Substituted pagan names, conditioned by Orthodoxy, became an intermediate stage in the transition of the Chuvash anthroponymicon to the Christian European way. However, distorted Russian names still function in the Chuvash language, reminiscent of another cultural reality that occurred in the recent past.

\section{ACKNOWLEDGMENTS}

The study was financially supported by the Russian Foundation for Basic Research and the Chuvash Republic as part of scientific project No. 18-412-210002 p_a.

\section{REFERNCE LIST}

1. Ashmarin N. I. (1928-1950). Dictionary of the Chuvash Language.

2. Egorov N. I. (1986). Female Personal Names of Lower Chuvash Pagans. Culture and Life of Lower Chuvash.

3. Egorova O. V. (2010). Traditional Birthing Rites of the Chuvash of the Volga-Ural Region.

4. Fedotov M. R. (1998). Dictionary of Chuvash non-Christian Personal Names.

5. Fomin E. V., Ivanova A. M. (2016). Dictionary of Chuvash Poetonyms.

6. Leont'eva A. A. (2006). Russian Personal Names in the Chuvash Language.

7. Magnitskii V. K. (1905). Chuvash Pagan Names.

8. Petrov L. P. (1986). Personal Names of Chuvash Pagans of the Zakamskii Region. Culture and Life of lower Chuvash.

9. Skvortsov M. I. (1968). Once Again about the Arabic-Persian Contribution to the Chuvash Vocabulary. 10. Yagafova E. A. (2009). Chuvash-Muslims in the XVIII - early XXI Centuries. 